\title{
Key West Nightshade, a New Experimental Host for Plant Viruses
}

\author{
Scott Adkins and Erin N. Rosskopf, U.S. Department of Agriculture, Agricultural Research Service, United States \\ Horticultural Research Laboratory, 2001 South Rock Road, Fort Pierce, FL 34945
}

\begin{abstract}
Adkins, S., and Rosskopf, E. N. 2002. Key West nightshade, a new experimental host for plant viruses. Plant Dis. 86:1310-1314.

Key West nightshade (Solanum bahamense) is a perennial solanaceous weed found in the extreme southern portion of Florida. It can be propagated by seed and cuttings and is absent from the noxious weed lists of all U.S. states. Its susceptibility to five viruses common to Florida was evaluated by mechanical inoculation of leaves with Tomato spotted wilt virus (TSWV), Tobacco mosaic virus (TMV), Pepper mild mottle virus (PMMoV), Cucumber mosaic virus (CMV), and a putative tobamovirus recently isolated from hibiscus in Florida (HV). TSWV induced chlorotic rings on inoculated leaves and mosaic and malformation of uninoculated leaves. CMV induced necrotic local lesions on inoculated leaves. No symptoms were observed following inoculation with TMV, PMMoV, or HV. TSWV, TMV, and PMMoV systemically infected $S$. bahamense as determined by the use of enzyme-linked immunosorbent assay, reverse transcription-polymerase chain reaction, viral-associated double-stranded RNA analysis, and/or indicator hosts. Active growth of infected plants continued for 7 months following inoculation, making $S$. bahamense suitable for long-term maintenance of viruses in planta. We suggest that $S$. $b a$ hamense may be a useful host for virus culture collections and for studies involving large numbers of virus isolates where fresh, infected tissue is continuously required.
\end{abstract}

Although plant virologists generally focus their research on economically important crops, there are several instances where noncrop plants merit consideration. Such plants, frequently weeds, are important (i) reservoirs for viruses causing economic losses in crop plants, (ii) experimental hosts for detection, identification, maintenance, or easier manipulation of such viruses, and (iii) targets for biocontrol by viruses $(8,18)$. Weeds have long been known to harbor plant viruses and the vectors that transmit them $(6,14)$. Since they can serve as an important source of inoculum for crop plants, numerous weed species have been explored (naturally infected and/or experimentally inoculated) as reservoir hosts. A great many of these are in the Solanaceae $(3,4,7,15,20,27)$, and some weed species, e.g., Datura stramonium, have proven to be useful experimental hosts (6). Additional experimental and/or indicator hosts from multiple plant genera are available to virologists. Many of these are also in the Solanaceae $(5,19)$, especially the genus Nicotiana $(25,26)$. Although a few of these species are perennials $(16,17)$, the vast majority of

Corresponding author: Scott Adkins

E-mail: SAdkins@ushrl.ars.usda.gov

Accepted for publication 11 July 2002.

Publication no. D-2002-0926-01R

This article is in the public domain and not copyrightable. It may be freely reprinted with customary crediting of the source. The American Phytopathological Society, 2002. experimental hosts are annuals. A perennial plant species easily manipulated under experimental conditions and susceptible to commonly studied plant viruses may find use in virus culture collections and research with viruses that lose infectivity upon storage.

As part of our research on Tomato spotted wilt virus (TSWV) diversity, we have tested many solanaceous plants for their response to infection. American black nightshade, Solanum americanum, is regularly employed as an indicator host in our studies. However, S. americanum, like all other plants tested to date, has a very short useful life following TSWV infection. Short host life represents a limitation for our research because we have determined that fresh leaf tissue is a better source of inoculum, viral RNA, and viral protein than frozen leaf tissue. We therefore have a need for a TSWV host that will continue active growth following infection.

In this report, we examined the "virus range" of a previously unstudied perennial member of the Solanaceae, Key West nightshade (Solanum bahamense L.). The term "virus range," coined by Christie and Crawford (9), is an assessment of the viruses to which a particular host plant is susceptible. Representatives of three different virus genera were assayed. While the virus range reported was not developed by testing all possible viruses that may infect $S$. bahamense, the results with the five viruses assessed here demonstrate the utility of this plant as a new experimental host. We show that $S$. bahamense is a useful long-term host for TSWV, Tobacco mosaic virus (TMV), and Pepper mild mottle virus (PMMoV), viruses generally confined to short-lived herbaceous plants, because it continues to grow for many months following inoculation.

\section{MATERIALS AND METHODS}

Field collection of $S$. bahamense. While hiking on Bahia Honda in the Florida Keys, we observed a single shrub-like tree with red-orange fruit (Fig. 1) that were morphologically similar to those of $S$. americanum. As part of our continuing search for a long-term TSWV host suited to our needs, we collected fruit and extracted seeds, which we subsequently planted in the greenhouse. Three seeds germinated and grew into plants identified as Key West nightshade, S. bahamense. These three plants were maintained as stock plants for propagation.

Inoculation of $S$. bahamense. In addition to TSWV, four other viruses commonly found in Florida were used to make an initial determination of the "virus range" of $S$. bahamense and to evaluate its suitability as a host for use in virology experiments. Viruses tested were: TMV strain U1 (kindly provided by Dennis Lewandowski), Florida isolates of PMMoV (2), a putative tobamovirus recently detected in hibiscus (HV; 1$), \mathrm{Cu}$ cumber mosaic virus (CMV; kindly provided by Mark Gooch), and TSWV. Inocula were prepared from virus-infected leaf tissue of $D$. stramonium (TSWV), tobacco (Nicotiana tabacum cv. Xanthi; TMV, PMMoV, and CMV), and Chenopodium quinoa $(\mathrm{HV})$. Inoculum for TSWV was prepared by homogenization of infected leaf tissue in $0.5 \%$ (wt/vol) sodium sulfite containing $1 \%(\mathrm{wt} / \mathrm{vol})$ Celite as an abrasive using a mortar and pestle. Inocula for TMV, PMMoV, HV, and CMV were prepared by homogenization of the in fected leaf tissue in $20 \mathrm{mM}$ sodium phosphate buffer ( $\mathrm{pH}$ 7.0) containing $1 \%$ (wt/vol) Celite. Each of five independent groups of $S$. bahamense plants (two or three plants each) was inoculated with one of the five viruses. Cheesecloth was used to apply inocula to several marked leaves per plant. A sixth group of plants was mock-inoculated with phosphate buffer.

Determination of "virus range." Inoculated plants were monitored weekly for symptom development. Following the first appearance of symptoms on TSWVinoculated (marked) leaves 1 month postinoculation, uninoculated leaves were collected from all plants and tested for the 
presence of the input virus by at least two of the following techniques: enzyme-linked immunosorbent assay (ELISA), reverse transcription-polymerase chain reaction (RTPCR), viral-associated double-stranded (ds) RNA analysis, and/or indicator host inoculation. A commercially available ELISA kit (Agdia, Elkhart, IN) routinely employed in our laboratory was used to test for TSWV. RT-PCR was used for detection of TSWV, PMMoV, and TMV according to standard protocols $(22,23)$ with virus-specific primers (Table 1). Briefly, first strand cDNA was synthesized by Moloney murine leukemia virus reverse transcriptase (Promega, Madison, WI) at $50^{\circ} \mathrm{C}$ for $45 \mathrm{~min}$. This was followed by 30 cycles of PCR amplification with $\mathrm{Taq}$ polymerase at $94^{\circ} \mathrm{C}$ for $45 \mathrm{~s}, 55^{\circ} \mathrm{C}$ for $45 \mathrm{~s}$, and $72^{\circ} \mathrm{C}$ for $1 \mathrm{~min}$. Products were analyzed by electrophoresis on native $2 \%$ agarose gels and detected by ethidium bromide staining. DsRNA analysis was selected for examination of infection by TMV, PMMoV, HV, and CMV, as these four viruses are amenable to detection by this method. DsRNA was extracted from 7-g samples of uninoculated $S$. $b a-$ hamense leaf tissue following a protocol previously published (24), although only a single cycle of cellulose chromatography was used. DsRNA was analyzed by electrophoresis on native $5 \%$ polyacrylamide gels and detected by silver staining using a commercially available kit (Bio-Rad, Hercules, CA). Upper noninoculated leaf tissue from inoculated $S$. bahamense plants was homogenized and used to inoculate appropriate indicator hosts for TMV, PMMoV, HV, and CMV based on the literature $(1,10,28,29)$.

\section{RESULTS}

Culture of $S$. bahamense. Although the three plants started from field-collected seed grew vigorously and flowered profusely (Fig. 1A and B) in our greenhouse, no fruit were produced. This was in striking contrast to $S$. americanum, which produces abundant fruit in our greenhouse. Hand pollination of $S$. bahamense flowers was necessary for fruit production, but even then, fruit set was quite poor (Fig.
1C). Vegetative propagation via cuttings from the original three plants was found to be a much easier and more expedient means of plant production, especially with the use of commercially available auxin (Rootone, Green Light Co., San Antonio, TX). Cuttings rooted and were ready for inoculation in 2 weeks, while 2 to 3 months were required for seed to germinate and produce plants suitable for propagation by cuttings.

"Virus range" of $S$. bahamense. Chlorotic rings and ring patterns developed on $S$. bahamense leaves inoculated with TSWV by 4 weeks postinoculation (Fig. 2A) on two of three inoculated plants. Symptoms of systemic infection, including malformation of leaves (Fig. 2B), a generalized mosaic, and localized necrosis, were readily apparent several weeks later on these plants, an observation confirmed by the use of ELISA and RT-PCR (Table 2). RT-PCR with TSWV-specific primers TSWV723 and TSWV722 (Table 1) amplified the expected 620-bp product from total RNA extracted from the TSWV-infected
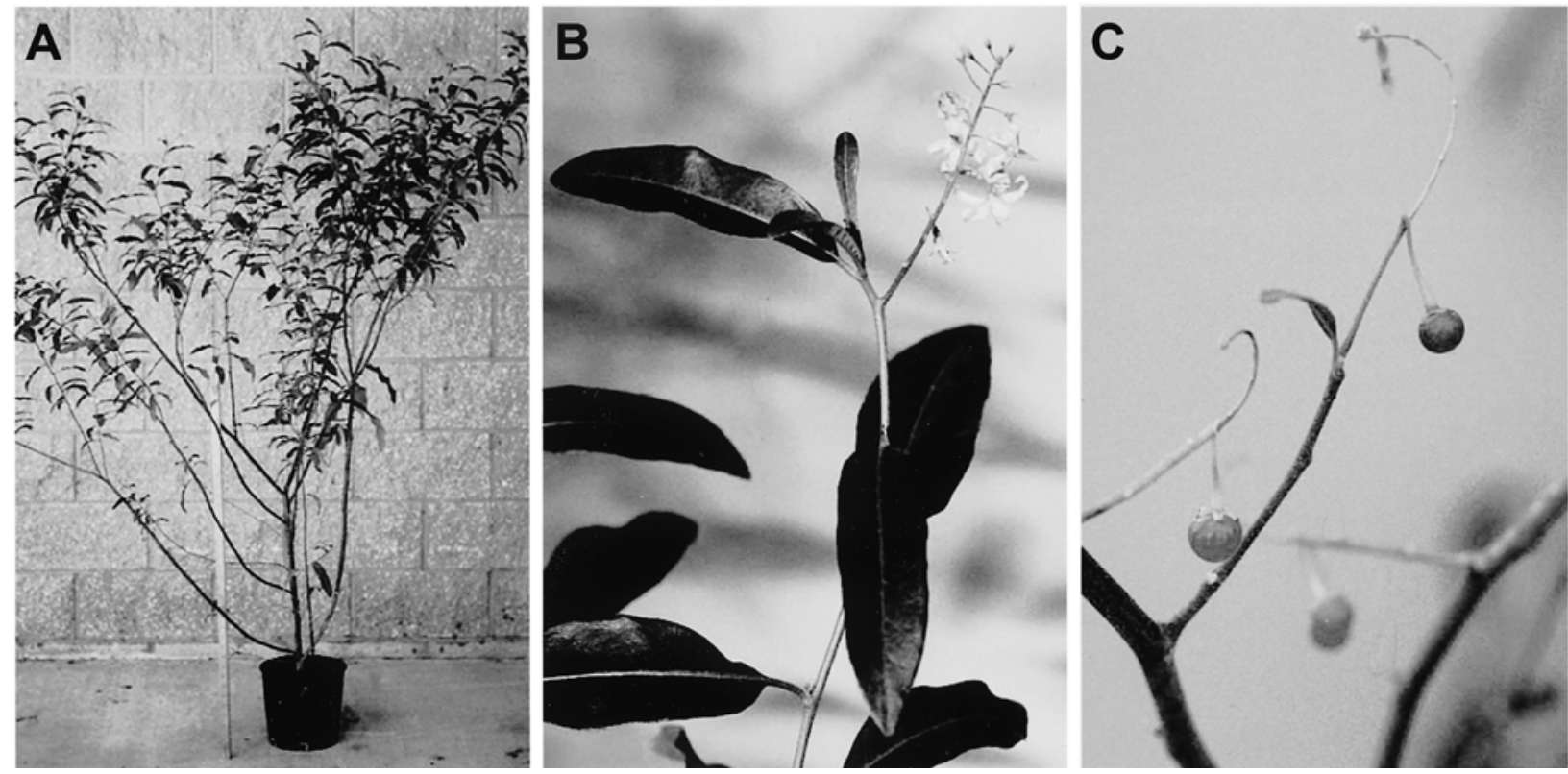

Fig. 1. Solanum bahamense plants greenhouse-grown from field-collected seed. A, Whole plant with meter stick for scale. B, Oblong to lanceolate leaves and racemose inflorescence with purple corolla. C, Glabrous immature fruit set following hand pollination. Note poor fruit set compared to number of flowers on inflorescence in (B).

Table 1. Oligonucleotides used for reverse transcription-polymerase chain reaction amplification

\begin{tabular}{|c|c|c|c|}
\hline Name & Sequence $\left(5^{\prime}-3^{\prime}\right)$ & Region of viral $\mathbf{R N A}^{\mathrm{a}}$ & Product size (bp) \\
\hline TSWV723 & CACAAGGCAAAGACCTTGAG & $2698-2717^{\mathrm{b}}$ & 620 \\
\hline TSWV722 & GCTGGAGCTAAGTATAGC & $2098-2118^{c}$ & \\
\hline TMV3'vc & TGGGCCCCTACCGGGGG & $6379-6395^{\mathrm{b}}$ & 360 \\
\hline TMV5'vAccI & TAATACGACTCACTATAGGTATTTTTACAACAATTACCAAC & $6054-6087^{c}$ & \\
\hline PMMoV3'vcA & AATGGGCCCTGGGCCGCTACCCGCGGTTC ${ }^{\mathrm{e}}$ & $6338-6357^{\mathrm{b}}$ & 419 \\
\hline tob268CPv & GAYWCHMGDAAYAGRRYHHATHGA & $5949-5971^{\mathrm{c}}$ & \\
\hline
\end{tabular}

${ }^{a}$ Indicated in nucleotides on the Tomato spotted wilt virus genomic S RNA segment or the Tobacco mosaic virus and Pepper mild mottle virus genomic RNA.

${ }^{\mathrm{b}}$ Complementary to the viral genome in this region.

${ }^{\mathrm{c}}$ Corresponds to the viral genome in this region.

${ }^{\mathrm{d}}$ Includes a T7 RNA polymerase promoter (underlined).

${ }^{\mathrm{e}}$ Includes an ApaI site (underlined) and three additional 5' nucleotides to optimize restriction. 
but not the mock-inoculated plants (Fig. 3, lanes 6 and 7).

Red-brown local lesions developed on $S$. bahamense leaves inoculated with CMV by 2 weeks postinoculation (Fig. 2C) on both of the inoculated plants. No symptoms of systemic infection were apparent, an observation verified by the use of dsRNA analysis and indicator hosts (Table 2). No CMV-associated dsRNA was recovered from uninoculated leaves of $S$. $b a$ hamense (Fig. 4, lane 6). However, an endogenous dsRNA was detected in the CMV-inoculated and all other $S$. $b a$ hamense plants assayed, including the mock-inoculated plants (compare Fig. 4, lane 2, with lanes 3 to 6). At 9 weeks postinoculation with CMV, sap from uninoculated $S$. bahamense leaves did not contain CMV as judged by the absence of symptoms on indicator hosts (Table 2).

Although no symptoms were observed through 7 months postinoculation, TMV and PMMoV both systemically infected all inoculated $S$. bahamense plants as determined by the use of RT-PCR, dsRNA analysis, and indicator hosts (Table 2). RTPCR with the TMV-specific primers TMV3've and TMV5'vAccI or PMMoVspecific primer PMMoV3'vcA and degenerate tobamovirus primer tob $268 \mathrm{CPv}$ (Table 1) amplified the expected 360- and 419-bp products from total RNA extracted from the TMV-infected (Fig. 3, lane 3) and
PMMoV-infected plants (Fig. 3, lane 5), respectively. No products were amplified from total RNA extracted from mockinoculated plants (Fig. 3, lanes 2 and 4). DsRNA analysis provided additional support for systemic infection of $S$. bahamense by both TMV and PMMoV, as evidenced by the isolation of a dsRNA from both TMVand PMMoV-inoculated plants that comigrated with the TMV dsRNA marker (Fig. 4, lanes 1, 3, and 4). As late as 7 months postinoculation with TMV or PMMoV, uninoculated $S$. bahamense leaves were an excellent inoculum source as judged by the symptoms on indicator hosts (Table 2).

As with the two recognized tobamoviruses, TMV and PMMoV, no symptoms
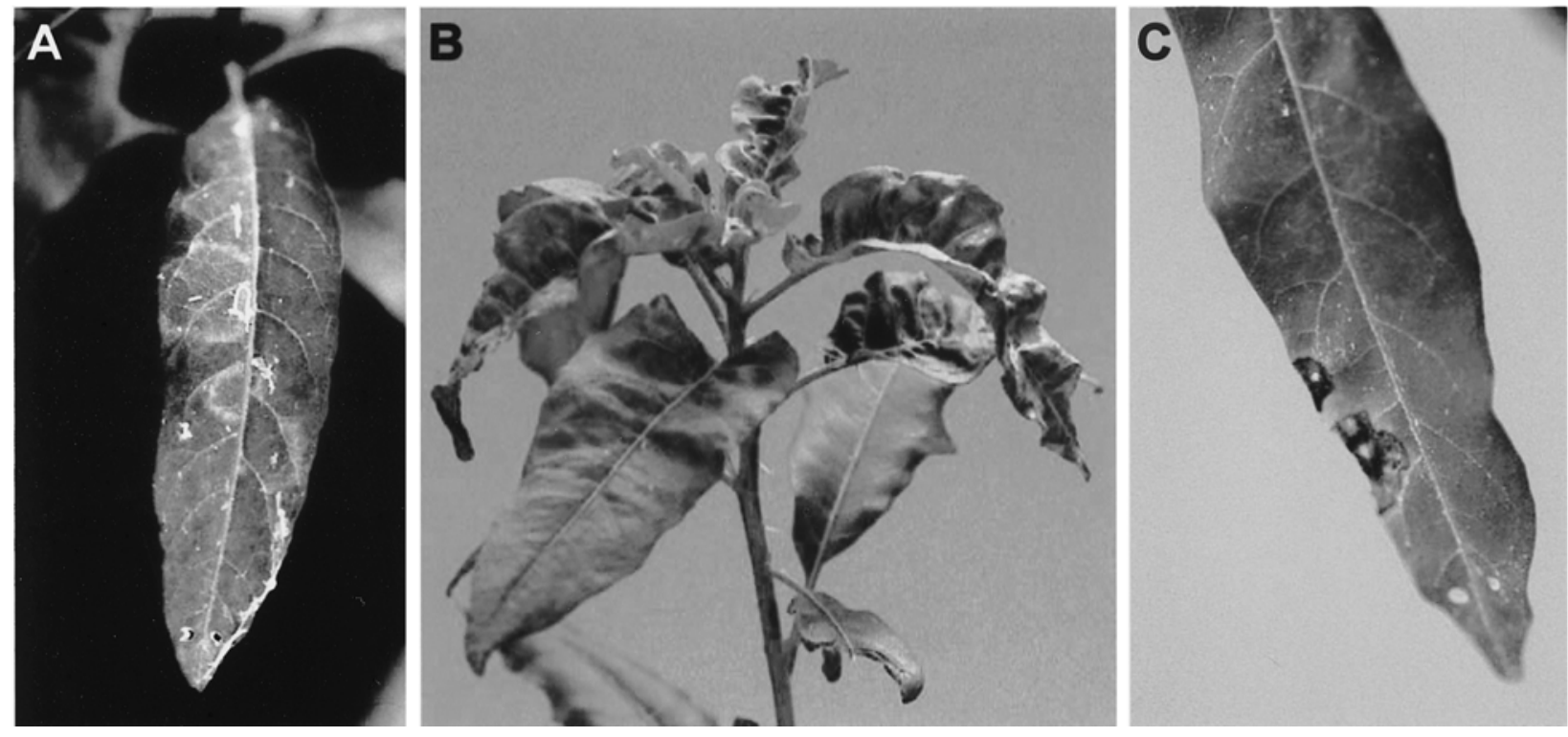

Fig. 2. Symptoms of virus infection in inoculated Solanum bahamense plants. A, Large (1 to $2 \mathrm{~cm}$ ) chlorotic rings on inoculated leaf following inoculation with Tomato spotted wilt virus (TSWV). B, Malformation of uninoculated leaves on TSWV-inoculated plant. Note thorns on stem. C, Small (2 to 3 mm) red-brown necrotic local lesions following inoculation with Cucumber mosaic virus.

Table 2. Determination of "virus range" of Solanum bahamense by enzyme-linked immunosorbent assay (ELISA), reverse-transcription polymerase chain reaction (RT-PCR), viral-associated double-stranded RNA analysis (dsRNA), and inoculation of indicator hosts

\begin{tabular}{|c|c|c|c|c|c|c|}
\hline \multirow[b]{2}{*}{ Virus } & \multirow[b]{2}{*}{ ELISA } & \multirow[b]{2}{*}{ RT-PCR } & \multirow[b]{2}{*}{ dsRNA } & \multicolumn{3}{|c|}{ Indicator host } \\
\hline & & & & Syr & ms & Species \\
\hline Tomato spotted wilt virus & $t^{\mathrm{a}}$ & + & $\mathrm{ND}^{\mathrm{b}}$ & ND & & \\
\hline \multirow[t]{6}{*}{ Cucumber mosaic virus } & ND & ND & - & - & $\mathrm{NS}^{\mathrm{c}}$ & Nicotiana benthamiana \\
\hline & & & & & NS & Nicotiana tabacum cv. Xanthi \\
\hline & & & & & NS & Nicotiana tabacum cv. Xanthi nc \\
\hline & & & & & NS & Nicotiana glutinosa \\
\hline & & & & & NS & Datura stramonium \\
\hline & & & & & NS & Cucumis sativus \\
\hline \multirow[t]{6}{*}{ Tobacco mosaic virus } & ND & + & + & + & SN & Nicotiana benthamiana \\
\hline & & & & & SM & Nicotiana tabacum cv. Xanthi \\
\hline & & & & & LL & Nicotiana tabacum cv. Xanthi nc \\
\hline & & & & & LL & Nicotiana rustica \\
\hline & & & & & LL & Datura stramonium \\
\hline & & & & & LL & Chenopodium quinoa \\
\hline \multirow[t]{5}{*}{ Pepper mild mottle virus } & ND & + & + & + & LL & Nicotiana tabacum cv. Xanthi nc \\
\hline & & & & & LL & Nicotiana glutinosa \\
\hline & & & & & LL & Nicotiana rustica \\
\hline & & & & & LL & Nicotiana sylvestris \\
\hline & & & & & LL & Datura stramonium \\
\hline Hibiscus virus & ND & ND & - & - & NS & Chenopodium quinoa \\
\hline
\end{tabular}

${ }^{a}$ Systemic infection of Solanum bahamense confirmed (+) or not (-) by technique indicated.

b $\mathrm{ND}=$ not determined.

${ }^{\mathrm{c}} \mathrm{NS}=$ no symptoms, $\mathrm{SN}=$ systemic necrosis, $\mathrm{SM}=$ systemic mosaic, $\mathrm{LL}=$ necrotic local lesions. 
were observed following inoculation with the putative tobamovirus HV. However, unlike TMV and PMMoV, HV did not systemically infect any of the three inoculated $S$. bahamense plants as determined by the use of dsRNA analysis and indicator hosts (Table 2). No HV-associated dsRNA was recovered from uninoculated leaves of S. bahamense (Fig. 4, lane 5). At 10 weeks postinoculation with $\mathrm{HV}$, sap from uninoculated $S$. bahamense leaves did not contain $\mathrm{HV}$ as judged by the absence of symptoms on C. quinoa (Table 2).

\section{DISCUSSION}

This report demonstrates that $S$. $b a$ hamense meets our needs as a long-lived TSWV host. We work with many isolates of TSWV in a single experiment, and $S$. bahamense provides a means of keeping fresh, infected tissue for multiple isolates available simultaneously for months on end. This report also suggests that $S$. $b a$ hamense may find more general application as a perennial host for viruses of herbaceous plants, making another experimental tool available to plant virologists. Additional research is required to develop a more complete "virus range" for this species, but the current report demonstrates its usefulness as a long-term host for one tospovirus and two tobamoviruses.

Many other members of the Solanaceae, especially those in the genus Nicotiana, have previously been demonstrated to be hosts for a plethora of plant viruses $(25,26)$. One widely used Nicotiana species is $N$. benthamiana, which has been known for nearly 30 years to be susceptible to many plant viruses $(9,21)$. Most of these solanaceous species are annual plants with short life cycles, frequently made shorter by virus infection. While this has little impact on the use of these species for detection, identification, and/or propagation of viruses, it is a major limitation for longterm maintenance of viruses such as TSWV in these plants.

Most prior research has focused on developing herbaceous plants to facilitate the study of viruses of woody perennial ornamental and fruit crops $(11,12)$. Notable exceptions to the herbaceous host trend are working research collections of viruses of perennial fruit crops, e.g., citrus, which are maintained in the crop species (13). Several perennial ornamental species in the Solanaceae have also been explored for this purpose $(16,17)$.

This report documents several characteristics that make $S$. bahamense suitable as a perennial host for viruses that generally infect annual crops. Our original three plants have been growing for a year and a half in the greenhouse. Although they were maintained in large containers and allowed to grow quite large $(>1 \mathrm{~m}$ as seen in Fig. $1 \mathrm{~A})$, this was only to maintain sufficient tissue for propagation. Plants used in experiments were routinely maintained in 4- inch pots (up to 7 months) and regularly trimmed to maintain a height of $30 \mathrm{~cm}$ or less. New growth on TSWV-, TMV-, and PMMoV-infected plants was always infected. Vegetative propagation allows for rapid production of $S$. bahamense cuttings once a stock plant is established. Vegetative propagation also eliminates plant-toplant variation that can sometimes arise in experimental hosts grown from seed. Inefficient fruit production by $S$. bahamense is a good trait because it makes escape of this plant into the environment unlikely, a fact noted by its absence on noxious weed lists for all U.S. states. On a practical level, $S$. bahamense has numerous thorns on both its stems (Fig. 2C) and leaves. This can lead to sore fingers for the incautious vi-

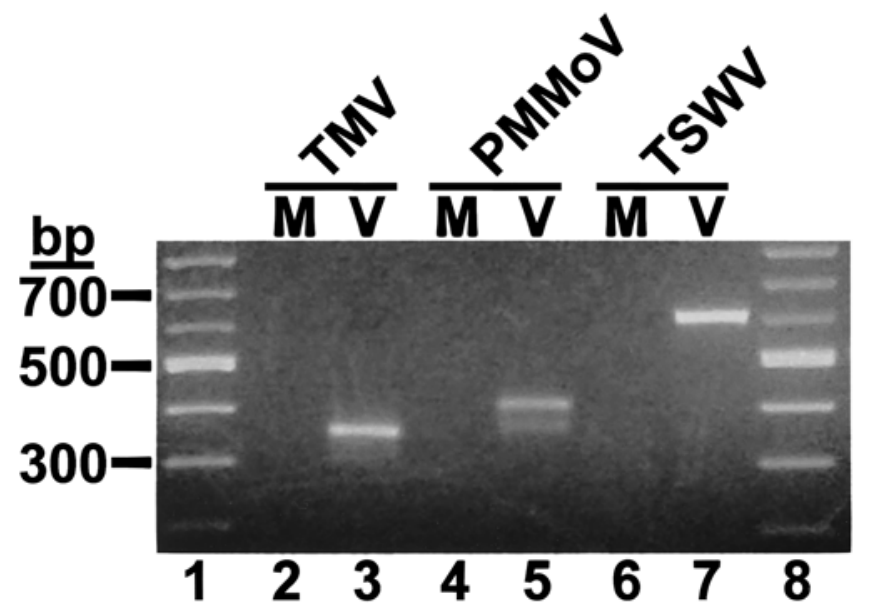

Fig. 3. Detection of systemic infection in inoculated Solanum bahamense plants by reverse transcription-polymerase chain reaction (RT-PCR). Total RNA was extracted from uninoculated leaves of mock- (M; lanes 2, 4, and 6) and virus-inoculated (V; lanes 3, 5, and 7) S. bahamense plants, amplified by RT-PCR with virus specific primers, analyzed by native electrophoresis on a $2 \%$ agarose gel, and stained with ethidium bromide. TMV = Tobacco mosaic virus, $\mathrm{PMMoV}=$ Pepper mild mottle virus, and TSWV = Tomato spotted wilt virus. Lanes 1 and 8 contain markers with sizes in base pairs (bp) indicated to the left of the gel.

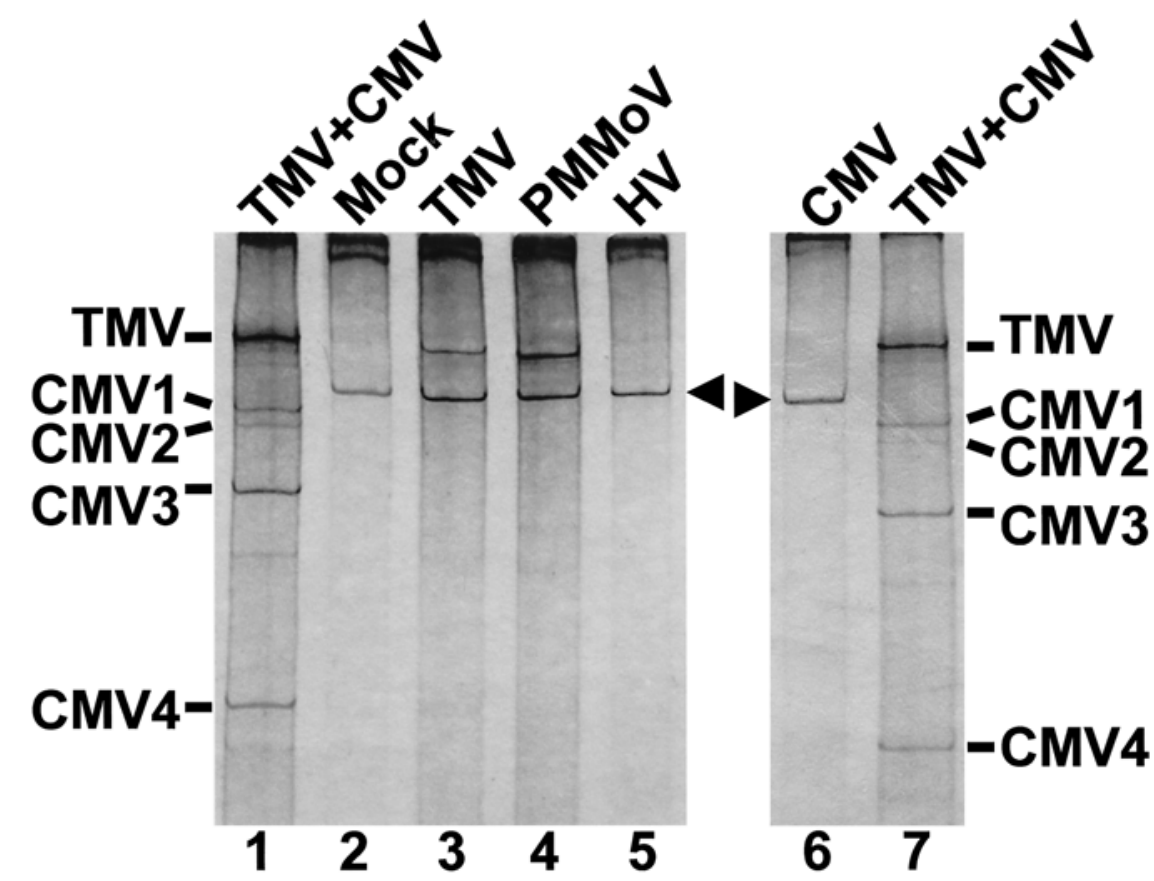

Fig. 4. Detection of systemic infection in inoculated Solanum bahamense plants by viral-associated double-stranded (ds) RNA analysis. DsRNA was extracted from uninoculated leaves of mock- (lane 2) and virus-inoculated (lanes 3 to 6) $S$. bahamense plants, analyzed by native electrophoresis on a $5 \%$ polyacrylamide gel and stained with silver. TMV = Tobacco mosaic virus, $\mathrm{PMMoV}=$ Pepper mild mottle virus, $\mathrm{HV}=$ hibiscus tobamovirus, and $\mathrm{CMV}=$ Cucumber mosaic virus. A mixture of TMV and CMV dsRNAs isolated from Nicotiana tabacum cv. Xanthi was used for reference (lanes 1 and 7) with positions of the one TMV dsRNA and the four CMV dsRNAs indicated to the sides of the gel. The position of an endogenous $S$. bahamense dsRNA is indicated with a triangle. 
rologist but has no effect on viral RNA or protein isolation! While $S$. bahamense was found to be a systemic albeit symptomless host for TMV and PMMoV, it was not susceptible to infection by HV. This suggests that it is not universally susceptible to tobamoviruses and demonstrates the difficulty of accurately predicting susceptibility to one member of a virus genus from results with other members of that same genus. Finally, S. bahamense was observed to contain an endogenous dsRNA (Fig. 4, lane 2), a phenomenon previously documented in other species including several members of the Solanaceae (24).

Many noncrop species in the genus Solanum have previously been shown to host viruses naturally $(7,14,15,20)$ and/or experimentally $(4,6,19)$, but to the best of our knowledge, this is the first report of $S$. bahamense being a host for any plant virus. While many excellent experimental hosts are available to plant virologists, the current report demonstrates that useful experimental hosts remain to be discovered, a fact noted by van Dijk and colleagues (26) 15 years ago.

\section{ACKNOWLEDGMENTS}

We thank Larry Markle and Barry Davis for helping us identify the original seedlings of $S$. bahamense, Carrie Vanderspool for excellent technical assistance, Thomas L. German for providing primers TSWV722 and TSWV723 and Dennis J. Lewandowski and Mark E. Hilf for valuable discussions and critical reviews of the manuscript.

\section{LITERATURE CITED}

1. Adkins, S. 2001. Detection and characterization of a virus from hibiscus. (Abstr.) Phytopathology 91:S2.

2. Adkins, S., Lamb, E. M., Roberts, P. D., Gooch, M. D., Breman, L., and Shuler, K. D. 2001. Identification of Pepper mild mottle virus in commercial bell pepper in Florida. Plant Dis. 85:679.

3. Alegbejo, M. D. 1999. Physalis micrantha L., a weed host of pepper veinal mottle virus. J. Veg. Crop Prod. 5:59-66.
4. Barradas, M. M., Alexandre, M. A. V., and Vicente, M. 1979. Wild solanaceous as experimental hosts of viruses. II. Solanum lycocarpum St. Hil., S. mammosum L. and S. robustum Wendl. Arq. Inst. Biol. Sao Paulo 46:117-125.

5. Barradas, M. M., and Ferrari, J. T. 1992. Petunia integrifolia var. integrifolia, an experimental host of plant viruses. Arq. Inst. Biol. Sao Paulo 59:43-48.

6. Bautista, R. C., Mau, R. F. L., Cho, J. J., and Custer, D. M. 1995. Potential of tomato spotted wilt tospovirus plant hosts in Hawaii as virus reservoirs for transmission by Frankliniella occidentalis (Thysanoptera: Thripidae). Phytopathology 85:953-958.

7. Bedford, I. D., Kelly, A., Banks, G. A., Briddon, R. W., Cenis, J. L., and Markham, P. G. 1998. Solanum nigrum: An indigenous weed reservoir for a tomato yellow leaf curl geminivirus in southern Spain. Eur. J. Plant Pathol. 104:221-222.

8. Charudattan, R., Zettler, F. W., Cordo, H. A., and Christie, R. G. 1980. Partial characterization of a potyvirus infecting the milkweed vine, Morrenia odorata. Phytopathology 70:909-913.

9. Christie, S. R., and Crawford, W. E. 1978. Plant virus range of Nicotiana benthamiana. Plant Dis. Rep. 62:20-22.

10. Francki, R. I. B., Mossop, D. W., and Hatta, T. 1979. Cucumber mosaic virus. CMI/AAB Descriptions of Plant Viruses No. 213.

11. Fulton, R. W. 1966. Mechanical transmission of viruses of woody plants. Annu. Rev. Phytopathol. 4:79-102.

12. Garnsey, S. M. 1968. Additional non-citrus hosts for the Florida isolate of citrus variegation virus. Phytopathology 58:1433-1434.

13. Garnsey, S. M., Civerolo, E. L., Gumpf, D. J., Yokomi, R. K., and Lee, R. F. 1991. Development of a worldwide collection of citrus tristeza virus isolates. Pages 113-120 in: Proc. Conf. Int. Org. Citrus Virol. 11th. IOCV, Riverside, $\mathrm{CA}$

14. Groves, R. L., Walgenbach, J. F., Moyer, J. W., and Kennedy, G. G. 2002. The role of weed hosts and tobacco thrips, Frankliniella fusca, in the epidemiology of Tomato spotted wilt virus. Plant Dis. 86:573-582.

15. Hobbs, H. A., Eastburn, D. M., D’Arcy, C. J., Kindhart, J. D., Masiunas, J. B., Voegtlin, D. J., Weinzierl, R. A., and McCoppin, N. K. 2000. Solanaceous weeds as possible sources of Cucumber mosaic virus in southern Illinois for aphid transmission to pepper. Plant Dis. 84:1221-1224

16. Horváth, J. 1991. Lycium species (Family: Solanaceae) as new experimental hosts of plant viruses. Acta Phytopathol. Ent. Hung. 26:353-363.

17. Horváth, J. 1996. Ornamental Physalis species as perennial virus hosts. Acta. Hortic. 432:204-210.

18. Hull, R. 2002. Matthews' Plant Virology, 4th ed. Academic Press, San Diego, CA. pp. 632-634.

19. Kazinczi, G., and Horváth, J. 1998. Solanum nigrum L. as a new experimental host of melandrium yellow fleck bromovirus and sowbane mosaic sobemovirus. Acta Phytopathol. Ent. Hung. 33:27-30.

20. McGovern, R. J., Polston, J. E., and Mullahey, J. J. 1994. Solanum viarum: Weed reservoir of plant viruses in Florida. Int. J. Pest Manag. 40:270-273.

21. Quacquarelli, A., and Avgelis, A. 1975. Nicotiana benthamiana Domin, as host for plant viruses. Phytopathol. Mediterr.14:36-39.

22. Sambrook, J., and Russell, D. W. 2001. Molecular Cloning: A Laboratory Manual, 3rd ed. Cold Spring Harbor Laboratory, Cold Spring Harbor, NY. pp. 8.51-8.53.

23. Strommer, J., Gregerson, R., and Vayda, M. 1993. Isolation and characterization of plant mRNA. Pages 49-65 in: Methods in Plant Molecular Biology and Biotechnology. B. R. Glick and J. E. Thompson, eds. CRC, Boca Raton, FL.

24. Valverde, R. A., Nameth, S. T., and Jordan, R. L. 1990. Analysis of double-stranded RNA for plant virus diagnosis. Plant Dis. 74:255-258.

25. van der Want, J. P. H., Boerjan, M. L., and Peters, D. 1975. Variability of some plant species from different origins and their suitability for virus work. Neth. J. Plant Pathol. 81:205-216.

26. van Dijk, P., van der Meer, F. A., and Piron, P G. M. 1987. Accessions of Australian Nicotiana species as indicator hosts in the diagnosis of plant virus diseases. Neth. J. Plant Pathol. 93:73-85.

27. Vicente, M., Chagas, C. M., and July, J. R. 1979. Three wild Solanaceae plants as natural hosts for a potyvirus. Fitopathol. Bras. 4:73-76.

28. Wetter, C., and Conti, M. 1988. Pepper mild mottle virus. CMI/AAB Descriptions of Plant Viruses No. 330.

29. Zaitlin, M., and Israel, H. W. 1975. Tobacco mosaic virus. CMI/AAB Descriptions of Plant Viruses No. 151. 